RASĀYAN J. Chem.

Vol. 13 | No. 1 |761 - 766| January - March | 2020 ISSN: 0974-1496 | e-ISSN: 0976-0083 | CODEN: RJCABP

RJC http://www.rasayanjournal.com http://www.rasayanjournal.co.in

\title{
EXTRACTION OF Co(II) AND Cu(II) FROM WASTE MATERIALS WITH SEMICARBAZONE OF 4- NITROBENZALDEHYDE
}

\author{
Jaspal Singh*, R. D. Kaushik, Payal Devi and Preeti Das \\ Department of Chemistry, Gurukula Kangri Vishwavidyalaya, Haridwar, Uttrakhand, India \\ *E-mail: sjs2874@yahoo.com
}

\begin{abstract}
The studies on extraction of $\mathrm{Co}(\mathrm{II})$ and $\mathrm{Cu}$ (II) from aqueous solutions of waste material into the organic phase using 4-nitrobenzaldehydesemicarbazone were found to be sufficient. However, it was observed that the extraction increases when the $\mathrm{pH}$ of the solution was increased and extraction was found to be higher for $\mathrm{Cu}$ (II) in comparison with Co(II). This supports the following type of extraction mechanism.

$\left(\mathrm{M}^{\mathrm{n}+}\right) \mathrm{aq}+\mathrm{m}(\mathrm{HL})$ org $=\left[\mathrm{ML}_{\mathrm{n}}(\mathrm{m}-\mathrm{n}) \mathrm{HL}\right]$ org $+\mathrm{n}\left(\mathrm{H}^{+}\right)$aq.

The extraction decreases with increased concentration of metal ion whereas the Sandell sensitivity and metal/ligand ratio were found to be $0.0049 \mu \mathrm{gcm}^{-2}$ and $1: 2$ respectively. The determination of $\mathrm{Co}$ (II) and $\mathrm{Cu}(\mathrm{II}) \mathrm{has}$ also been executed in the existence of foreign ions.
\end{abstract}

Keywords: Solvent Extraction, 4-Nitrobenzaldehydesemicarbozone, Semicarbazone, Thiosemicarbazones.

(C) RASĀYAN. All rights reserved

\section{INTRODUCTION}

The waste material at the industrial site has evolved as a major problem, for which the solvent extraction method would be preferably best for the extraction of precious metal from them. Semi and thiosemicarbazones are a class of compounds possessing a wide spectrum of medicinal properties. ${ }^{1,36}$ The carcinostatic properties of metal complexes of thiosemicarbazide and thiosemicarbazones have captivated great attention. ${ }^{2}$ The 1-methyl isatin thiosemicarbazone (Marboran) is a specific preventive drug of smallpox. ${ }^{3}$ For detecting zinc by luminescence method the salicylaldehyde semicarbazone has also been used. $^{4}$

Phenanthrenequinone monosemicarbazone (PQSC) was used as an extractive indicator in the complexometric determination of cobalt with EDTA by using 8-10 drops of a $0.3 \%$ solution of the indicator in $\mathrm{CHCl}_{3}$, the titration can be successfully carried out at room temperature over the $\mathrm{pH}$ range $\mathrm{e}^{5}$ 8.3- 10.0.

The phenanthrene Quinone monothiosemicarbazone reagent was also used ${ }^{6}$ for the precise and efficient determination of $\mathrm{Fe}(\mathrm{II})$ and $\mathrm{Fe}(\mathrm{III})$.

The preparation, stability and ionization constants of 2-hydroxy-3-methyl-2-cyclopentane-1onethiosemicarbazone (I) and 3-methyl-1,2-cyclopentanedionebisthiosemicarbazone(II) were reported ${ }^{7}$. For trace determination of $\mathrm{Zn}$ (II) and $\mathrm{Bi}(\mathrm{II})$ one of the significant compound $\mathrm{Ni}$ (II)-EDTA-6methylepicolinealdehyde azine was used. ${ }^{8}$

The fluorometric properties of the oxime thiosemicarbazone, azine and 2-pyridylhydrazone derivatives of 3-hydroxy-2-pyridine carbaldehyde ${ }^{9}$; spectrophotometric determination of vanadium with salicylaldehyde thiosemicarbazone ${ }^{10}$; dibenzoyl methane thiosemicarbazone as an analytical reagent for determination of $\mathrm{Pt}(\mathrm{IV}), \mathrm{Co}(\mathrm{II}), \mathrm{Mo}(\mathrm{II}), \mathrm{Pd}(\mathrm{II}), \mathrm{Ni}(\mathrm{II})$, and $\mathrm{Cu}(\mathrm{II})^{11-12}$ has also been studied.

Some more documented literature involve studies such as the development of 1,3cyclohexanedionebisthiosemicarbazone monohydrochloride (1,3-CHTD.HCl) for spectrophotometric determination of Nickel (II); spectrophotometric determination of chromium(VI) using cyclohexane-1,3dionebisthiosemicarbazone monohydrochloride ${ }^{14}$; determination of $\mathrm{Fe}(\mathrm{III})$ and $\mathrm{Mn}$ (II) based on the

Rasayan J. Chem., 13(1), 761-766(2020)

http://dx.doi.org/10.31788/RJC.2020.1315563

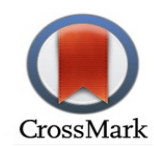


RASĀYAN J. Chem.

Vol. 13 | No. 1 |761 - 766| January - March | 2020

oxidation of 2-hydroxybenzaldehyde thiosemicarbazone by $\mathrm{H}_{2} \mathrm{O}_{2}$ in an ammonical medium ${ }^{15}$. One another method ${ }^{16}$ has reported the spectrophotometer determination of iron (III) and $\mathrm{Cu}$ (II). The determination of 1,2-diamino cyclohexane tetraacetic acid involves dissolution in $\mathrm{EtOH}$, the addition of 2-hydroxy benzaldehyde thiosemicarbazone, $\mathrm{H}_{2} \mathrm{O}_{2}, \mathrm{NH}_{3}$ and then $\mathrm{Mn}^{+2}$ as a catalyst and measuring the fluorescence excitation at $365 \mathrm{~nm}$, emission at $440 \mathrm{~nm}^{17}$. A spectrophotometric $\operatorname{method}^{18}$ was used to determine the protonation constants of the biacetyl(2-pyridyl)hydrazone-thiosemicarbazone. A new synthesized reagent 5,5-dimethyl- 1,2,3-cyclohexane trione- 1,2- dioxime-3- thiosemicarbazone was spectrophotometrically studies for determination of $\mathrm{Fe}^{19}$. Recently, Extracted $\mathrm{Co}$ (II) with 2,4-dihydroxy acetophenone thiosemicarbazone from $\mathrm{NH}_{4} \mathrm{Cl}-\mathrm{NH}_{4} \mathrm{OH}$ buffer solution at $\mathrm{pH} 6.5 \mathrm{in} \mathrm{BuOH}$. $\mathrm{Co}$ (II) forms a 1:1 complex with thiosemicarbazone. ${ }^{20}$ An extraction photometric determination method ${ }^{21}$ for $\mathrm{Cu}$ and $\mathrm{Fe}$ is based on the extraction of their complexes with quinalene-2-aldehydethiosemicarbazone at $\mathrm{pH} 7.5$ into $\mathrm{CHCl}_{3}$.

A new extractive spectrophotometric method ${ }^{22}$ for the determination of Mo is based on the extraction of the orange-red Mothio-cyanato-2-acetylpyridinethiosemicarbazone complex into $\mathrm{CHCl}_{3}$ from $\mathrm{HCl}$. Manganese is a conventional trace element for human beings. ${ }^{37}$ Some of the recent reports include the $\mathrm{Mn}^{\mathrm{II}}$ catalyzed periodate oxidation of aromatic amine. ${ }^{23-26}$ It is worth mentioning that some methods ${ }^{27-28}$ have been developed for the determination of anilines by employing the reactions of periodate in presence of $\mathrm{Mn}^{\text {II }}$. There are a few reports accessible within the literature concerning the kinetic spectrophotometric estimation of $\mathrm{Mn}^{\mathrm{II}}$, based on the reduction of periodate ion by some substrates. ${ }^{29-33}$ The reports are available on stability constant for the ternary intermediate complex formation between aromatic amine, $\mathrm{Mn}^{\mathrm{II}}$ and periodate ${ }^{34}$. Most of the precious metal is very essential for human beings, so these are extracted from waste material. This paper describes the extraction of metal ions $\mathrm{Co}$ (II) and $\mathrm{Cu}$ (II) from the waste material of aqueous solutions into the organic phase using 4-nitrobenzaldehydesemicarbazone.

\section{EXPERIMENTAL}

\section{Materials and Methods}

All the chemicals were of AR grade. Copper acetate (E. Merk), Cobalt Chloride (E. Merk), Semicarbezidehydrochloride (E. Merk), 4-nitrobenzaldehyde(E. Merk), Acetone(CDH), Chloroform(CDH), Hydrochloric acid(CDH), Disodium hydrogen phosphate(E. Merk), Citric acid(E. Merk), Borax(CDH) Sodium acetate(E. Merk), Acetic acid(E. Merk), Potassium dihydrogen phosphate(E. Merk) and solutions were prepared by using triply distilled water. 4-nitrobenzaldehydesemicarbazone was prepared by the reported method ${ }^{35}$. The concentration of metal ions in the aqueous phase was determined by using the atomic absorption spectrophotometer (Perkin -Elmer atomic absorption spectrophotometer model 3100). The $\mathrm{pH}$ measurements of the aqueous phase before and after equilibration were carried on a combined electrode $\mathrm{pH}$ meter (Toshiniwal).

\section{Synthesis of 4-Nitrobenzaldehydesemicarbazone}

Semicarbazide hydrochloride $(1.12 \mathrm{~g}, 0.01 \mathrm{~mole})$ in $20 \mathrm{ml}$ of methanol was added to the solution and 4nitrobenzaldehyde $(1.50 \mathrm{~g}, 0.01$ mole) in methanol $(20 \mathrm{ml})$. The mixture was refluxed for $4 \mathrm{hr}$ with constant stirring. The excess of the solvent was removed by the distillation and creamish color solid was separated by cooling. It was recrystallized from methanol with $85 \%$ yield, M.P.- $201{ }^{\circ}$ C. The nitrogen in the semicarbazone was determined by Kjeldahl method ${ }^{36}$. The observed $\%$ of $\mathrm{N}$ was 26.79 and the calculated \% of $\mathrm{N}$ was 26.92. It is soluble in chloroform, methanol, ethanol and DMF. The ligand was used as extractants for the solvent extraction of $\mathrm{Co}$ (II) and $\mathrm{Cu}$ (II) at different $\mathrm{pH}$.

Notably, $\mathrm{HNO}_{3}, \mathrm{H}_{2} \mathrm{SO}_{4}$, and $\mathrm{HCl}$-based solutions were commonly employed for dissolving precious metal from waste materials. The solution of metal ions was prepared by dissolving waste material in $\mathrm{H}_{2} \mathrm{SO}_{4}$ or $\mathrm{HCl}$. Further, the metal ions solutions were diluted by distilled water. The concentration of the copper and cobalt in the diluted sample was determined on a Perkin- Elmer atomic absorption spectrophotometer. First of all, a standard solution $\left(10^{-2} \mathrm{M}\right)$ of $\mathrm{Cu}(\mathrm{II})$ was prepared and then diluted to prepare four solutions containing 1.0ppm, $2.0 \mathrm{ppm}, 3.0 \mathrm{ppm}$, and $4.0 \mathrm{ppm} \mathrm{Cu}(\mathrm{II})$ ions. These solutions were used to calibrate the apparatus used for outlining the plot between absorbance and concentration of the metal ion concluding the concentration of that particular metal ion in the sample solution. 
RASĀYAN J. Chem.

Vol. 13 | No. 1 |761 - 766| January - March | 2020

Similarly, the standard solution of $10^{-2} \mathrm{M}$ of $\mathrm{Co}(\mathrm{II})$ prepared in distilled water then diluted to prepare five solutions containing $2.0 \mathrm{ppm}, 4.0 \mathrm{ppm}, 5.0 \mathrm{ppm}$, and $7.0 \mathrm{ppm}$ of Co(II) ions. These solutions were used to calibrate the instrument. The concentration of $\mathrm{Co}$ (II) in the solutions before and after extraction was determined directly on the spectrophotometer.

\section{Extraction Procedure}

Equal volumes $(20.0 \mathrm{ml})$ of aqueous phase consisting of the metal ion in the buffer solution of the desired $\mathrm{pH}$ and organic phase $\left(\mathrm{CHCl}_{3}\right)$ containing the extractants were shaken at room temperature $\left(35.0{ }^{\circ} \mathrm{C}\right.$ $\pm 3.0^{\circ} \mathrm{C}$ ) for 15 minutes to ensure complete equilibration. The clear phase separation was determined by atomic absorption spectrophotometer. The same procedure was adopted for $2^{\text {nd }}$ extraction of the aqueous phase. The calculations of the concentration of metal ions in the organic phase were determined by noting the difference of original metal ion concentration in the aqueous phase before and after equilibration. The distribution ratio (D) was calculated by the ratio of the concentration of metal ions in the organic phase and concentration of metal ions in the aqueous phase, the percentage extraction $(\% \mathrm{E})$ was calculated by(concentration of a metal ion in organic phase / total concentration of metal ion) $\times 100$.

\section{RESULTS AND DISCUSSION}

The extraction of metal ions $\mathrm{Co}(\mathrm{II})$ and $\mathrm{Cu}(\mathrm{II})$ from aqueous solutions into the organic phase using 4nitrobenzaldehydesemicarbazone was found to be sufficient. However, it was observed that the extraction increases when the $\mathrm{pH}$ of the solution was increased and extraction was found to be higher for $\mathrm{Cu}$ (II) as compared to Co (II).

\section{Speciation of $\mathbf{p H}$}

The present extraction of $\mathrm{Co}$ (II) and $\mathrm{Cu}$ (II) with 4- nitrobenzaldehydesemicarbazone in chloroform as a function of $\mathrm{pH}$ was studied using the buffer of three different $\mathrm{pH}$. The buffer used as follows:

$\mathrm{pH}=2.60 ; \mathrm{Na}_{2} \mathrm{HPO}_{4}+$ Citric acid

$\mathrm{pH}=4.40 ; \mathrm{CH}_{3} \mathrm{COONa}+$ acetic acid

$\mathrm{pH}=6.89 ; \mathrm{Na}_{2} \mathrm{HPO}_{4}+\mathrm{KH}_{2} \mathrm{PO}_{4}$

The results of the extraction are given in Tables- 1 and 2.

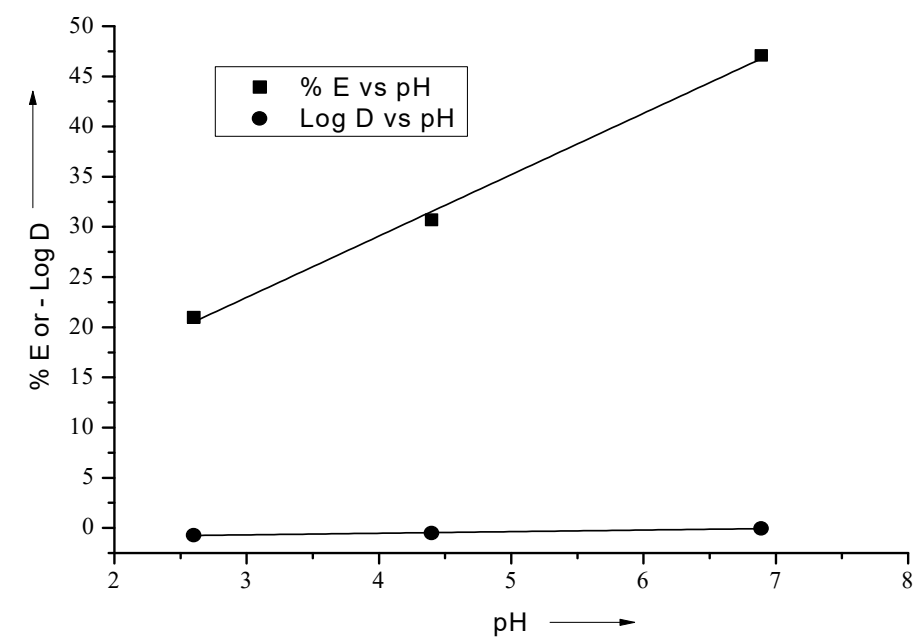

Fig.-1: Effect of of $\mathrm{pH}$ on Extraction of $\mathrm{Cu}^{\mathrm{II}}$ with 4-Nitrobenzaldehyde Semicarbazone at $[\mathrm{NBS}]=2 \times 10^{-2} \mathrm{M},[\mathrm{Cu}(\mathrm{II})]=1 \times 10^{-2} \mathrm{M}$ 
RASĀYAN J. Chem.

Vol. 13 | No. 1 |761 - 766| January - March | 2020

Table-2: Extraction of Copper with 4-Nitrobenzaldehyde Semicarbazone as a Function of $\mathrm{pH}$ $[\mathrm{NBS}]=2 \times 10^{-2} \mathrm{M},[\mathrm{Cu}(\mathrm{II})]=1 \times 10^{-2} \mathrm{M}$

\begin{tabular}{c|c|c|c}
\hline $\mathrm{pH}$ & \% Extraction & $\mathrm{D}$ & $-\operatorname{LogD}$ \\
\hline 2.60 & 21.01 & 0.2660 & 0.7276 \\
\hline 4.40 & 30.72 & 0.3110 & 0.5072 \\
\hline 6.89 & 47.10 & 0.8902 & 0.0506 \\
\hline
\end{tabular}

Table-3: Extraction of Co with 4-Nitrobenzaldehydesemicarbazone as a Function of $\mathrm{pH}$ $[\mathrm{NBS}]=2 \times 10^{-2} \mathrm{M},[\mathrm{Co}(\mathrm{II})]=1 \times 10^{-2} \mathrm{M}$

\begin{tabular}{c|c|c|c}
\hline $\mathrm{pH}$ & \% of Extraction & $\mathrm{D}$ & -Log D \\
\hline 2.60 & 18.75 & 0.2307 & 0.6369 \\
4.40 & 20.01 & 0.6425 & 0.6081 \\
6.89 & 39.05 & 0.6425 & 0.1921 \\
\hline
\end{tabular}

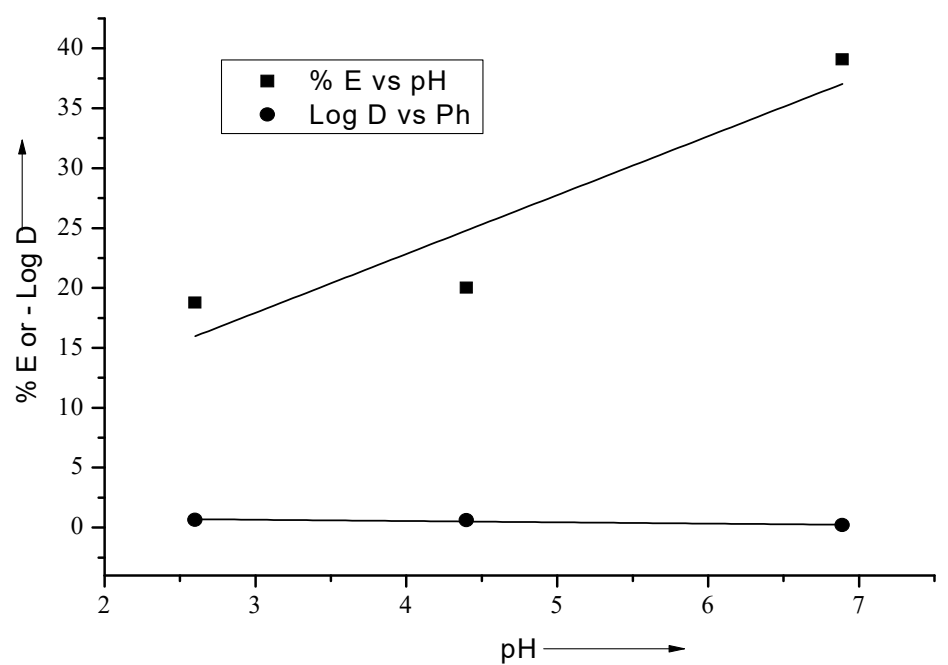

Fig.-2: Effect of $\mathrm{pH}$ on Extraction of $\mathrm{Co}^{\mathrm{II}}$ with 4-Nitrobenzaldehyde Semicarbazone at $[\mathrm{NBS}]=2 \times 10^{-2} \mathrm{M},[\mathrm{Co}(\mathrm{II})]=1 \times 10^{-2} \mathrm{M}$

It was found that $\%$ increase with an increase in $\mathrm{pH}$ of the aqueous phase. This supports the following type of extraction mechanism-

$\left(\mathrm{M}^{\mathrm{n}+}\right) \mathrm{aq}+\mathrm{m}(\mathrm{HL})$ org $=\left[\mathrm{ML}_{\mathrm{n}}(\mathrm{m}-\mathrm{n}) \mathrm{HL}\right] \operatorname{org}+\mathrm{n}\left(\mathrm{H}^{+}\right) \mathrm{aq}$.

Further studies were carried out at $\mathrm{pH}=6.89$ for both $\mathrm{Cu}$ (II) and $\mathrm{Co}$ (II). The plot of log $\mathrm{D}$ versus $\mathrm{pH}$ at constant metal ion $[\mathrm{Co}(\mathrm{II})$ and $\mathrm{Cu}(\mathrm{II})]$ and semicarbazone concentration gave a straight line( Fig.-1 and 2) with a slope of nearly $\sim 1.0-1.6$ indicating the possibility of coordination of the semicarbazone to the metal ions in the neutral ketonic form.

\section{Speciation of Metal ion Concentration}

The effect of $\mathrm{Cu}(\mathrm{II})$ and $\mathrm{Co}(\mathrm{II})$ ion concentration within the range $\left(1.0-5,0 \times 10^{-3}\right)$ on the distribution ratio was studied at constant ligand concentration $\left(10^{-2} \mathrm{~m}\right)$ and constant $\mathrm{pH} 6.89$ as shown in Fig.-3. The results are given in Tables-3 and 4. It was observed that the extraction was almost independent of the metal ions concentration in the above range and there was only a slight decrease in the percent extraction with an increase in metal ions concentration. This rules out the possibility of extraction of any polymeric species in the above-mentioned concentration range. 
RASĀYAN J. Chem.

Vol. 13 | No. 1 |761 - 766| January - March | 2020

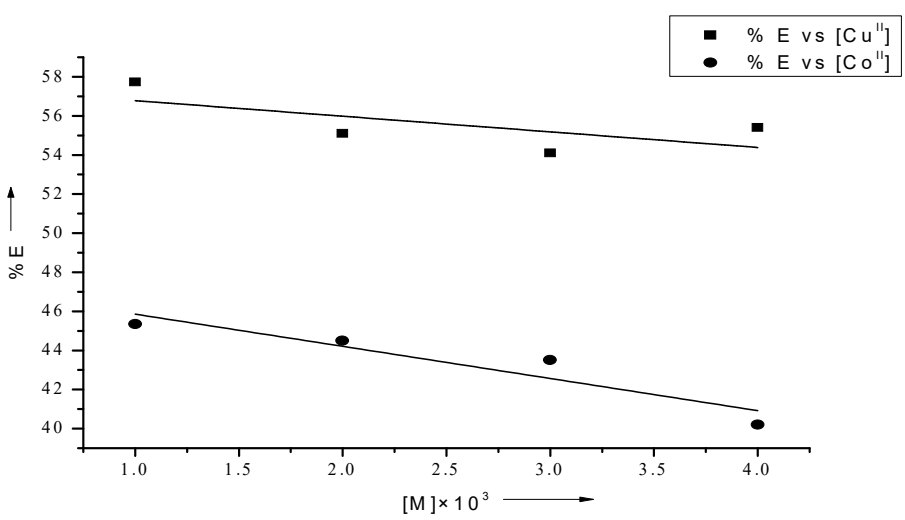

Fig.-3: Effect of Metal Ion Concentration of the Extraction of $\mathrm{Co}^{\mathrm{II}}$ and $\mathrm{Cu}^{\mathrm{II}}$ with 4-Nitrobenzaldehyde Semicarbazone at $[\mathrm{NBS}]=1 \times 10^{-2} \mathrm{M}, \mathrm{pH}=6.89$

Table-3: Extraction of $\mathrm{Cu}(\mathrm{II})$ with 4-Nitrobenzaldehyde Semicarbazone as a Function of Metal Ion Concentration. $[\mathrm{NBS}]=1 \times 10^{-2} \mathrm{M}, \mathrm{pH}=6.89$

\begin{tabular}{c|c}
\hline $\mathrm{Cu}(\mathrm{II})$ Concentration (M) & $\% \mathrm{E}$ \\
\hline $1 \times 10^{-3}$ & 57.73 \\
\hline $2 \times 10^{-3}$ & 55.10 \\
\hline $3 \times 10^{-3}$ & 54.10 \\
\hline $5 \times 10^{-3}$ & 55.40 \\
\hline
\end{tabular}

Table-4: Extraction of Co(II) with 4-Nitrobenzaldehyde Semicarbazone as a Function of Metal Ion Concentration. $[\mathrm{NBS}]=1 \times 10^{-2} \mathrm{M}, \mathrm{pH}=6.89$

\begin{tabular}{c|c}
\hline Co(II) Concentration (M) & $\% \mathrm{E}$ \\
\hline $1 \times 10^{-3}$ & 45.35 \\
\hline $2 \times 10^{-3}$ & 44.50 \\
\hline $3 \times 10^{-3}$ & 43.50 \\
\hline $5 \times 10^{-3}$ & 40.20 \\
\hline
\end{tabular}

\section{CONCLUSION}

Studies carried out on the extraction behaviour of $\mathrm{Cu}(\mathrm{II})$ and $\mathrm{Co}(\mathrm{II})$ using 4nitrobenzaldehydesemicarbazone at various $\mathrm{pH}$. The extraction was found to be more at $\mathrm{pH} 6.89$. Therefore, further studies such as the effect of metal ion concentration and the extractant on the extraction of $\mathrm{Cu}$ (II) and $\mathrm{Co}(\mathrm{II})$ were carried out at $\mathrm{pH} 6.89$ to obtain the optimum conditions. The effect of diluents on the extraction was not possible to study because of the insufficient solubility of the 4nitrobenzaldehydesemicarbazone.

\section{ACKNOWLEDGMENT}

The authors are thankful to Prof. Mala Nath, Department of Chemistry, I I T Roorkee for providing moral support and cooperation.

\section{REFERENCES}

1. Y. Marcus, Ion-Exchange and Solvent Extraction of Metal Complexes, Wiley Interscience, N. Y. (1969).

2. M.A. Ali and S.E. Livingstone, Coordination Chemistry Reviews, 13(2-3), 101(1974), DOI: 10.1016/50010-8545(00)80253-2

3. A. Albert, Australian Journal of Science, 30, 1(1967).

4. E.A. Bozhevol'nov, Reactive, 22,65(1958).

5. F. Kamil, S.K. Sindhwani and R. P. Singh, Annali di Chimica, 69, 373(1979).

6. P. P. Sinha, S. K. Sindhwani and R.P. Singh, Annali di Chimica, 73, 349(1983).

7. J. L. Rojas, J. M. Fernandiz and M. Valcarcel, Anales de Quimica, Ser B, 79, 397(1983).

8. A. Rios and M. Valcarcel, Analyst, 109, 1147(1984). 
RASĀYAN J. Chem.

Vol. 13 | No. 1 |761 - 766| January - March | 2020

9. R. Vazquez, T. A. Carciadi and J. M. Cano-Pavan, Talanta, 31(1), 29(1984), DOI:10.1016/00399140(84)80006-5

10. N.S.R. Reddy and D.V. Reddy, Journal of the Indian Institute of Science, 69, 133(1983).

11. J. Aznarez, M.A. Belarra and E. Measequer, Revista de la Academia de Ciencias Exactas, Físicas, Químicas y Naturales de Zaragoza, 37, 103(1982).

12. J. Aznarez, M.A. Belarra and E. Measequer, Revista de la Academia de Ciencias Exactas, Físicas, Químicas y Naturales de Zaragoza, 37, 95(1982).

13. K.H. Reddy and D.V. Reddy, Indian Journal of Chemistry Section A, 22A, 824(1983).

14. K.H. Reddy and D.V. Reddy, Analyst, 108, 1247(1983).

15. A. Moreno, M. Silva and D. Prez-Bendito, Analytica Chimica Acta, 159, 319(1984).

16. K.H. Reddy, G.K. Reddy, K.M.M.S. Prakash and D.V. Reddy, Indian Journal of Chemistry Section $A$, 23A, 535(1984).

17. A, Moreno, M. Silva, D. Prez Bandeto and M. Valcarcel, Quimica Analitica, 41c, 39(1985).

18. F. De Pablos, D.L. Gomez Ariza and F. Pino, Microchimica Acta, 1, 411(1985).

19. F. Salinas, S. Jimenez, C. Jaun and T.D. Galeano, Analytical Chemistry, 58, 824(1986).

20. A.V. Reddy, M.L.P. Reddy and Y.K. Reddy, Journal of Radioanalytical and Nuclear Chemistry, 86(6), 391(1984).

21. D.V. Khasnis and V.M. Shinde, Journal of the Indian Chemical Society, 61, 275(1984).

22. K.N. Thimmanh, H. Sankegowda and K.K. Murthy, Microchemical Journal, 32(1), 8(1985), DOI: 10.1016/0026-265X(85)90045-1

23. Sushma, R.D. Kaushik, M.M. Tiwari, M. Chawla and J. Singh, Rasayan Journal of Chemistry, 12(3), 1203(2019), DOI: 10.31788/RJC.2019.1235348

24. R.D. Kaushik, P. Sundriyal, P. Tyagi, P. Singh and J. Singh, International Journal of Chemical Science, 12(2), 600(2014).

25. R.D. Kaushik, J. Singh, Manila, M. Kaur and P. Singh, Bulletin of Chemical Reaction Engineering and Catalysis, 9(3), 182(2014), DOI:10.9767/bcrec.9.3.6823.182-191

26. K. Rawat, J. Singh, R.D. Kaushik and N. Khandelwal, Rasayan Journal of Chemistry, 11(3), 1328(2018), DOI: 10.31788/RJC.2018.1133095

27. R.D. Kaushik, R. Yadav, M.M. Tiwari, P. Rathi and J. Singh, Der Pharmacia Lettre, 6(4), 78(2014).

28. R.D. Kaushik, J. Singh, R. Saini, P. Tyagi and E. Kumari, Rasayan Journal of Chemistry, 10(2), 368(2017), DOI:10.7324/RJC.2017.1021656

29. R.D. Kaushik, R. Malik, O. Singh, Manila and J. Singh, International Journal of Chem Tech Research, 6(5), 2695(2014).

30. R.D. Kaushik, R. Malik, M.M. Tiwari, J. Singh and P. Singh, Research Journal of Pharmaceutical, Biological and Chemical Sciences, 5(3), 1963(2014).

31. R.D. Kaushik, J. Singh, P. Rathi, R. Saini and E. Kumari, Research Journal of Pharmaceutical, Biological and Chemical Sciences, 8(3), 1569(2017).

32. J. Singh, R.D. Kaushik, P. Tyagi, R. Saini and E. Kumari, Journal of Chemical and Pharmaceutical Research, 9(6), 74(2017).

33. R.D. Kaushik, J. Singh, R. Agarwal, P. Rathi and E. Kumari, Rasayan Journal of Chemistry, 10(2), 461(2017), DOI:10.7324/RJC.2017.1021690

34. A. I. Vogel, A Text Book of Practical Organic Chemistry, Longmans, London, 334(1968).

35. T.N. Srivastava and P.C. Kamboj, Systematic Analytical Chemistry, Vishal Publication, Delhi, 366(1985).

36. M. Nath, N. Sharma and C.L. Sharma, Synthesis and Reactivity in Inorganic and Metal-organic Chemistry, 20(5), 623(2006), DOI:10.1080/00945719008048160

37. J. Singh, M. Chawla and R. D. Kaushik, Inorganic Toxicity: Manganese, In. G. Matta and L. Gyjli (Eds.), Inorganic Toxicity: Environmental and Human Health, Lambert Publishing, Mauritius, 206219(2018).

[RJC-5563/2019] 